\title{
Pigmentiphaga litoralis sp. nov., a facultatively anaerobic bacterium isolated from a tidal flat sediment
}

\author{
Yi-Guang Chen, ${ }^{1,2} \dagger$ Yu-Oin Zhang, ${ }^{2,3}$ † Ke Huang, ${ }^{1}$ Shu-Kun Tang, ${ }^{2}$ \\ Yao Cao, ${ }^{1}$ Jin-Xiao Shi, ${ }^{1}$ Huai-Dong Xiao, ${ }^{1}$ Xiao-Long Cui ${ }^{2}$ \\ and Wen-Jun Li $\mathrm{i}^{2,4}$
}

Correspondence

Wen-Jun Li

wjli@ynu.edu.cn

Yi-Guang Chen

mchenjsu@yahoo.com.cn

\author{
${ }^{1}$ College of Bio-Resources and Environmental Science, Jishou University, Jishou, Hunan 416000, \\ PR China \\ ${ }^{2}$ The Key Laboratory for Microbial Resources of the Ministry of Education and Laboratory for \\ Conservation and Utilization Bio-Resources, Yunnan Institute of Microbiology, Yunnan University, \\ Kunming 650091, PR China \\ ${ }^{3}$ Institute of Medicinal Biotechnology, Chinese Academy of Medical Sciences \& Peking Union \\ Medical College, Beijing 100050, PR China \\ ${ }^{4}$ Guangdong Key Laboratory of Marine Materia Medica, South China Sea Institute of Oceanology, \\ Chinese Academy of Sciences, Guangzhou 510301, PR China
}

A novel Gram-negative, facultatively anaerobic, non-sporulating, non-motile, catalase- and oxidase-positive, rod-shaped bacterium (strain JSM $061001^{\top}$ ) was isolated from a tidal flat in the South China Sea, China. Growth occurred with 0-5\% (w/v) $\mathrm{NaCl}$ [optimum, 0.5-1\% (w/v) $\mathrm{NaCl}]$, at $\mathrm{pH}$ 5.0-10.0 (optimum, $\mathrm{pH} 7.0$ ) and at 4-35 ${ }^{\circ} \mathrm{C}$ (optimum, 25-30 ${ }^{\circ} \mathrm{C}$ ). The major cellular fatty acids were $C_{16: 0}$, cyclo $C_{17: 0}, C_{18: 1} \omega 7 c$ and $C_{16: 1}$. Strain JSM 061001 ${ }^{\top}$ contained ubiquinone Q-8 as the predominant respiratory quinone, and phosphatidylglycerol, phosphatidylethanolamine and an unidentified phospholipid as the polar lipids. The genomic DNA $\mathrm{G}+\mathrm{C}$ content was $65.5 \mathrm{~mol} \%$. Phylogenetic analysis based on 16S rRNA gene sequences indicated that strain JSM $061001^{\top}$ belongs to the family Alcaligenaceae and was related most closely to the type strains of the two recognized species of the genus Pigmentiphaga. The three strains formed a robust cluster in the neighbour-joining, maximum-parsimony and maximumlikelihood phylogenetic trees. Levels of DNA-DNA relatedness between strain JSM $061001^{\top}$ and the type strains of Pigmentiphaga daeguensis and Pigmentiphaga kullae were 15.8 and $10.5 \%$, respectively. The combination of phylogenetic analysis, DNA-DNA hybridization data, phenotypic characteristics and chemotaxonomic differences supported the view that strain JSM $061001^{\top}$ represents a novel species of the genus Pigmentiphaga, for which the name Pigmentiphaga litoralis sp. nov. is proposed. The type strain is JSM $061001^{\top}(=$ CCTCC AA207034 ${ }^{\top}=$ KCTC $22165^{\top}$ ).
The genus Pigmentiphaga, belonging to the family Alcaligenaceae (De Ley et al., 1986), was first proposed by Blümel et al. (2001) and was defined as comprising Gram-negative,

†These authors contributed equally to this work.

The GenBank/EMBL/DDBJ accession number for the 16S rRNA gene sequence of strain JSM $061001^{\top}$ is EU583723.

Maximum-parsimony and maximum-likelihood phylogenetic trees showing the position of strain JSM $061001^{\top}$ among other related taxa inferred from $16 \mathrm{~S}$ rRNA gene sequences, and a table detailing the fatty acid compositions of strain JSM $061001^{\top}$ and members of the genus Pigmentiphaga are available as supplementary material with the online version of this paper. motile or non-motile, non-sporulating, catalase- and oxidase-positive rods, with ubiquinone Q-8 as the predominant respiratory quinone and phosphatidylethanolamine as the major polar lipid. At the time of writing, the genus comprised two recognized species, Pigmentiphaga kullae and Pigmentiphaga daeguensis. During investigation of the microbial diversity of Naozhou Island, Leizhou Bay, South China Sea, China, a Gram-negative bacterium, designated strain JSM $061001^{\mathrm{T}}$, was isolated from a tidal flat sediment sample. Based on the results of a polyphasic taxonomic study, this strain is proposed to represent a novel species of the genus Pigmentiphaga. 
Strain JSM $061001^{\mathrm{T}}$ was isolated from a tidal flat sediment sample by plating 1:10 serial dilutions of the sample on trypticase soy agar (TSA; Difco) prepared with $50 \%(\mathrm{v} / \mathrm{v})$ seawater at $28{ }^{\circ} \mathrm{C}$ for 14 days. After primary isolation and purification, the isolate was preserved both on TSA slants at $4{ }^{\circ} \mathrm{C}$ and in trypticase soy broth (TSB; Difco) supplemented with $20 \%(\mathrm{v} / \mathrm{v})$ glycerol at $-80{ }^{\circ} \mathrm{C}$. Reference strains P. kullae DSM $13608^{\mathrm{T}}$ and P. daeguensis KCTC $12838^{\mathrm{T}}$ were obtained from the DSMZ (Deutsche Sammlung von Mikroorganismen und Zellkulturen) and the KCTC (Korean Collection for Type Cultures), respectively. Unless otherwise indicated, morphological and physiological studies were performed with cells grown on TSA at $28{ }^{\circ} \mathrm{C}$. Cell morphology was examined by using light microscopy (model BH 2; Olympus). Gram staining was carried out by using the standard Gram reaction combined with the $\mathrm{KOH}$ lysis test method (Gregersen, 1978). Growth was tested at various temperatures [0, 4 and $5-45{ }^{\circ} \mathrm{C}$ (at increments of $\left.\left.5{ }^{\circ} \mathrm{C}\right)\right]$ on TSA and at different $\mathrm{pH}$ values [5.0-11.0 (at increments of $0.5 \mathrm{pH}$ units) in TSB. Growth in the absence of $\mathrm{NaCl}$ and in the presence of various $\mathrm{NaCl}$ concentrations $[0.5 \%(\mathrm{w} / \mathrm{v})$, and $1.0-10.0 \%(\mathrm{w} / \mathrm{v}$, at increments of $1.0 \%)]$ was investigated by using TSB prepared according to the formula of the Difco medium except that no $\mathrm{NaCl}$ was used, and on some other media as controls, i.e. marine agar 2216 (MA; Difco), nutrient broth (NB; Difco) and ISP medium 2 agar (Shirling \& Gottlieb, 1966). Hydrolysis of aesculin and nitrate reduction were determined as described by Lányí (1987). Urease activity and hydrolysis of casein, gelatin, hypoxanthine, starch, Tweens 20, 40, 60 and 80, urea and xanthine were determined as described by Cowan \& Steel (1965). Anaerobic growth was determined on TSA at $28{ }^{\circ} \mathrm{C}$ for 2 weeks by using the GasPak Anaerobic System (BBL) according to the manufacturer's instructions, and reference strains P. kullae DSM $13608^{\mathrm{T}}$ and P. daeguensis KCTC $12838^{\mathrm{T}}$ were incubated under the same conditions as controls. Motility, and catalase and oxidase activities were detected as described by Chen $e t$ al. (2007). Other enzyme activities, acid production from carbohydrates, utilization of various substrates, and other physiological and biochemical properties were tested by using the API 20E, API 20NE, API $50 \mathrm{CH}$ and API ZYM systems (bioMérieux) according to the manufacturer's instructions. Morphological, cultural, physiological and biochemical characteristics of strain JSM $061001^{\mathrm{T}}$ are given in the species description below and in Table 1.

DNA was isolated according to Hopwood et al. (1985) and the $\mathrm{G}+\mathrm{C}$ content was determined by using the HPLC method (Mesbah et al., 1989). Genomic DNA extraction, PCR-mediated amplification of the 16S rRNA gene and purification of PCR products were performed as described by Cui et al. (2001). The resulting 16S rRNA gene sequence of strain JSM $061001^{\mathrm{T}}$ was compared with sequences obtained from public databases (GenBank/EMBL/DBBJ) to find the most closely related species. Phylogenetic analysis was performed by using the software package MEGA version 3.1 (Kumar et al., 2004) after multiple alignment of the sequence data by CLUSTAL_X (Thompson et al., 1997).
Table 1. Differential characteristics between strain JSM $061001^{\top}$ and recognized Pigmentiphaga species

Strains: 1, JSM $061001^{\mathrm{T}}$ (Pigmentiphaga litoralis sp. nov.; data from the present study); 2, P. daeguensis KCTC $12838^{\mathrm{T}}$ (Yoon et al., 2007); 3, P. kullae DSM $13608^{\mathrm{T}}$ (Blümel et al., 2001). +, Positive; -, negative.

\begin{tabular}{|lccc|}
\hline Characteristic & $\mathbf{1}$ & $\mathbf{2}$ & $\mathbf{3}$ \\
\hline Motility & - & - & + \\
Facultatively anaerobic & + & - & $-\star$ \\
growth & & & \\
Growth at: & & & \\
$4{ }^{\circ} \mathrm{C}$ & + & - & - \\
$40{ }^{\circ} \mathrm{C}$ & - & + & + \\
Production of: $\dagger$ & & & \\
Alkaline phosphatase & + & - & - \\
$\alpha$-Chymotrypsin & - & + & + \\
Cystine arylamidase & + & - & - \\
Esterase (C4) & - & + & + \\
$\alpha$-Glucosidase & + & - & - \\
$\beta$-Glucosidase & + & - & - \\
Major polar lipids $\ddagger$ & $\mathrm{PG}, \mathrm{PE}$ & $\mathrm{PG}, \mathrm{PE}, \mathrm{AL}$ & $\mathrm{PE}$ \\
DNA G+C content $(\mathrm{mol} \%)$ & 65.5 & 67.4 & 68.5 \\
& & & \\
\hline
\end{tabular}

${ }^{\star}$ Data from this study under identical conditions.

$\dagger$ Data for P. kullae DSM $13608^{\mathrm{T}}$ were taken from Yoon et al. (2007). $\ddagger \mathrm{AL}$, unidentified aminolipids; PE, phosphatidylethanolamine; PG, phosphatidylglycerol.

Distances (corrected according to Kimura's two-parameter model; Kimura, 1980) were calculated and clustering was performed with the neighbour-joining method (Saitou \& Nei, 1987). Maximum-likelihood (Felsenstein, 1981) and maximum-parsimony (Kluge \& Farris, 1969) trees were generated by using the treeing algorithms contained in the PHYLIP software package (Felsenstein, 1993). Bootstrap analysis was used to evaluate the tree topology of the neighbour-joining data by means of 1000 resamplings (Felsenstein, 1985). DNA-DNA hybridization was carried out at $45{ }^{\circ} \mathrm{C}$ by using photobiotin-labelled DNA probes and microdilution wells as described by Ezaki et al. (1989). A microplate spectrofluorimeter (GeminiXPS; Molecular Devices) was employed for fluorescence measurements.

The DNA G + C content of strain JSM $061001^{\mathrm{T}}$ was $65.5 \mathrm{~mol} \%$. A 1475-bp fragment of the 16S rRNA gene was amplified. Phylogenetic analysis based on 16S rRNA gene sequences revealed that the novel isolate was closely related to the type strains of the two recognized species of the genus Pigmentiphaga (Blümel et al., 2001), and these three strains formed a robust cluster in the neighbour-joining, maximumlikelihood and maximum-parsimony phylogenetic trees, in which strain JSM $061001^{\mathrm{T}}$ occupied a distinct subline branching at the periphery of the cluster and supported by a significant bootstrap resampling value (100\%) (see Fig. 1 and Supplementary Fig. S1 available in IJSEM Online). Levels of 16S rRNA gene sequence similarity between strain JSM $061001^{\mathrm{T}}$ and the type strains of $P$. daeguensis and P. kullae 


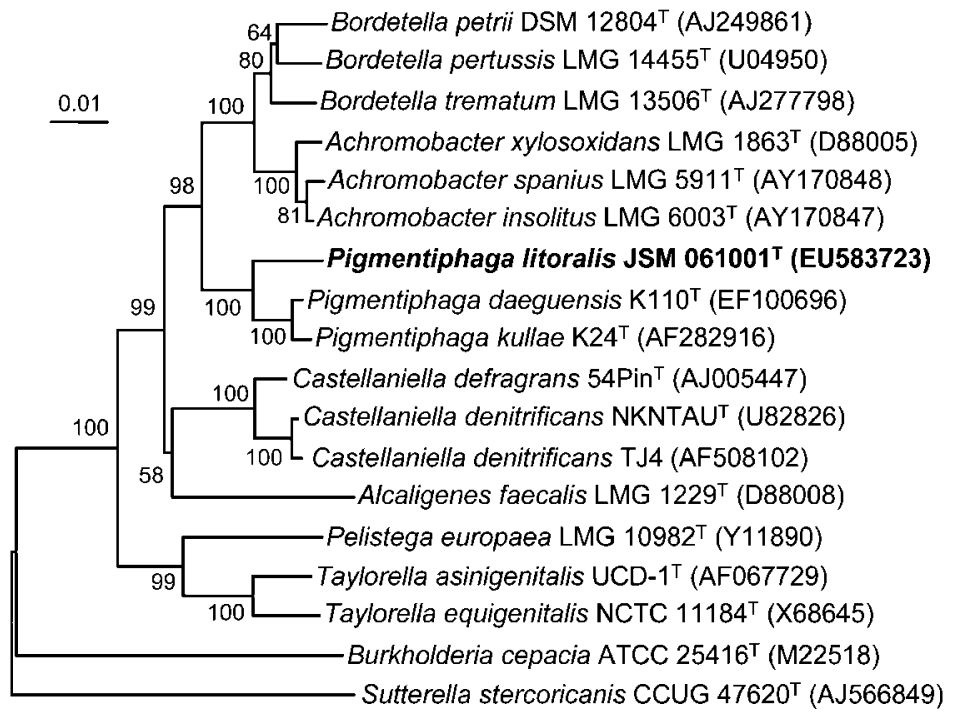

Fig. 1. Phylogenetic dendrogram based on 16S rRNA gene sequence analysis constructed by using the neighbour-joining method showing the position of strain JSM $061001^{\top}$ among related taxa. Numbers at nodes indicate bootstrap values ( $>50 \%$ ) based on a neighbour-joining analysis of 1000 resampled datasets. Bar, 1 substitution per $100 \mathrm{nt}$. were 97.9 and $97.8 \%$, respectively. By contrast, levels of DNA-DNA relatedness between strain JSM $061001^{\mathrm{T}}$ and the type strains of $P$. daeguensis and $P$. kullae were 15.8 and $10.5 \%$, respectively. It has been suggested that bacterial strains showing a level of DNA-DNA relatedness of less than $70 \%$ are not members of the same species (Wayne et al., 1987). Thus, the results of the phylogenetic analysis and DNA-DNA hybridization suggested that strain JSM $061001^{\mathrm{T}}$ was a member of the genus Pigmentiphaga distinct from P. daeguensis and P. kullae.

Isoprenoid quinones were analysed by HPLC as described by Groth et al. (1996). Polar lipids were extracted according to the method of Minnikin et al. (1984) and were then identified by two-dimensional TLC followed by spraying with appropriate detection reagents (Minnikin et al., 1984; Komagata \& Suzuki, 1987). Fatty acid compositions were determined as described by Sasser (1990) by using the Microbial Identification System (MIDI; Microbial ID) with cells grown on TSA after incubation for 3 days at $28{ }^{\circ} \mathrm{C}$. Chemotaxonomic data for strain JSM $061001^{\mathrm{T}}$ were compatible with its assignment to the genus Pigmentiphaga (Blümel et al., 2001). The predominant respiratory quinone of strain JSM $061001^{\mathrm{T}}$ was ubiquinone Q-8 (peak area ratio of approximately $96.9 \%$ ). The polar lipids of this strain consisted of phosphatidylglycerol, phosphatidylethanolamine and an unidentified phospholipid. The major fatty acids $\left(>10 \%\right.$ of the total) were $\mathrm{C}_{16: 0}$, cyclo $\mathrm{C}_{17: 0}$, $\mathrm{C}_{18: 1} \omega 7 c$ and $\mathrm{C}_{16: 1}$ (see Supplementary Table $\mathrm{S} 1$, available in IJSEM Online).

The results of phylogenetic analysis and the chemotaxonomic studies presented above supported the affiliation of strain JSM $061001^{\mathrm{T}}$ to the genus Pigmentiphaga (Blümel et al., 2001). However, it could be distinguished from recognized species of the genus based on a number of phenotypic properties (Table 1) and by its discriminative fatty acid profile (Supplementary Table S1), although the latter may have resulted partly from the different culture conditions used here and by Blümel et al. (2001) and Yoon et al. (2007). The presence of noticeable amounts of unbranched monounsaturated fatty acids (making up $34.8 \%$ of the total) and the low concentration of cyclo $\mathrm{C}_{19: 0} \omega 8 c$ in the fatty acid profile of strain JSM $061001^{\mathrm{T}}$ (Supplementary Table S1) distinguished it from $P$. daeguensis and P. kullae. Strain JSM $061001^{\mathrm{T}}$ differed markedly from the two recognized Pigmentiphaga species based on its ability to grow under anaerobic conditions and at a comparatively low temperature range (down to $4{ }^{\circ} \mathrm{C}$ ), and by its distinct activity profile of constitutive enzymes (Table 1). Together with the relatively low DNA G+C content of strain JSM $061001^{\mathrm{T}}$ (Table 1) and DNA-DNA hybridization data, the results of this polyphasic taxonomic study support the suggestion that strain JSM $061001^{\mathrm{T}}$ represents a novel species of the genus Pigmentiphaga, for which the name Pigmentiphaga litoralis sp. nov. is proposed.

\section{Description of Pigmentiphaga litoralis sp. nov.}

Pigmentiphaga litoralis (li.to.ra'lis. L. fem. adj. litoralis of or belonging to the seashore).

Cells are Gram-negative, non-sporulating, non-motile, catalase- and oxidase-positive, facultatively anaerobic, straight to slightly curved rods, approximately $0.5-$ $0.8 \mu \mathrm{m}$ wide and 1.0-2.5 $\mathrm{m}$ long. Colonies are yellowpigmented, somewhat convex and non-translucent, with glistening surfaces and circular/slightly irregular margins, and are 1-2 $\mathrm{mm}$ in diameter after incubation for 3 days at $28{ }^{\circ} \mathrm{C}$ on TSA. No diffusible pigments are produced. Growth occurs with 0-5\% (w/v) $\mathrm{NaCl}$ [optimum, 0.5-1 \% $(\mathrm{w} / \mathrm{v}) \mathrm{NaCl}$ ], at $\mathrm{pH}$ 5.0-10.0 (optimum, pH 7.0) and at 4-35 ${ }^{\circ} \mathrm{C}$ (optimum, $25-30{ }^{\circ} \mathrm{C}$ ). Aesculin is hydrolysed, but casein, gelatin, hypoxanthine, starch, L-tyrosine, Tweens 
20, 40, 60 and 80, urea and xanthine are not. VogesProskauer test and citrate utilization are positive. Nitrate is not reduced to nitrite. $\mathrm{H}_{2} \mathrm{~S}$ and indole are not produced. Positive for activity of acid phosphatase, alkaline phosphatase, arginine dihydrolase, cystine arylamidase, esterase lipase (C8), $\alpha$-glucosidase, $\beta$-glucosidase, lysine decarboxylase, ornithine decarboxylase and naphthol-AS-BI-phosphohydrolase (API ZYM and API 20E). No activity is observed for $\alpha$-chymotrypsin, esterase (C4), $\alpha$-fucosidase, $\alpha$-galactosidase, $\beta$-galactosidase, $\beta$-glucuronidase, $N$-acetyl$\beta$-glucosaminidase, lipase (C14), leucine arylamidase, $\alpha$ mannosidase, trypsin, urease or valine arylamidase (API ZYM and API 20E). Arabinose, glucose, inositol, malate, maltose, mannitol, mannose, rhamnose, sorbitol and sucrose are utilized, but $\mathrm{N}$-acetylglucosamine, adipic acid, amygdalin, capric acid, gluconate, melibiose and potassium phenylacetic acid are not (API 20E and API 20NE). Acids are produced from D-fructose, D-glucose, glycerol, Dlactose, maltose, D-mannitol, D-ribose, sucrose, trehalose and D-xylose (API $50 \mathrm{CH})$. Major fatty acids $(>10 \%$ of the total) are $\mathrm{C}_{16: 0}$, cyclo $\mathrm{C}_{17: 0}, \mathrm{C}_{18: 1} \omega 7 \mathrm{c}$ and $\mathrm{C}_{16: 1}$. The predominant respiratory quinone is ubiquinone $\mathrm{Q}-8$, and the polar lipids are phosphatidylglycerol, phosphatidylethanolamine and an unidentified phospholipid. The DNA G + C content of the type strain is $65.5 \mathrm{~mol} \%$ (HPLC method).

The type strain, JSM $061001^{\mathrm{T}}\left(=\mathrm{CCTCC}\right.$ AA207034 ${ }^{\mathrm{T}}=$ KCTC $22165^{\mathrm{T}}$ ), was isolated from a tidal flat sediment sample collected from the shore of Naozhou Island, Leizhou Bay, South China Sea, China.

\section{Acknowledgements}

This work was supported by grants from the National Natural Science Foundation of China (NSFC) (30660004, 30460004), Jishou University (jsdxkyzz200801, 07JDPHE148, 07JDPHE150, 07JDPHE151, 07JDPHE153), Ministry of Science and Technology, PR China (2006BAE01A01-9), the Yunnan Provincial Sciences and Technology Department (2005PY01-1, 2006C0006M, 2006C0004M), and the Ministry of Science and Technology of China (863 Program, no. 2007AA021306; 973 Program, no. 2004CB719601). W.-J. L. was supported by the Program for New Century Excellent Talents in University. We thank Professor Li Zhang for her excellent technical assistance.

\section{References}

Blümel, S., Mark, B., Busse, H.-J., Kämpfer, P. \& Stolz, A. (2001). Pigmentiphaga kullae gen. nov., sp. nov., a novel member of the family Alcaligenaceae with the ability to decolorize azo dyes aerobically. Int $J$ Syst Evol Microbiol 51, 1867-1871.

Chen, Y.-G., Cui, X.-L., Pukall, R., Li, H.-M., Yang, Y.-L., Xu, L.-H., Wen, M.-L., Peng, Q. \& Jiang, C.-L. (2007). Salinicoccus kunmingensis sp. nov., a moderately halophilic bacterium isolated from a salt mine in Yunnan, southwest China. Int J Syst Evol Microbiol 57, 2327-2332.

Cowan, S. T. \& Steel, K. J. (1965). Manual for the Identification of Medical Bacteria. London: Cambridge University Press.
Cui, X.-L., Mao, P.-H., Zeng, M., Li, W.-J., Zhang, L.-P., Xu, L.-H. \& Jiang, C.-L. (2001). Streptomonospora salina gen. nov., sp. nov., a new member of the family Nocardiopsaceae. Int J Syst Evol Microbiol 51, 357-363.

De Ley, J., Segers, P., Kersters, K., Mannheim, W. \& Lievens, A. (1986). Intra- and intergeneric similarities of the Bordetella ribosomal ribonucleic acid cistrons: proposal for a new family, Alcaligenaceae. Int J Syst Bacteriol 36, 405-414.

Ezaki, T., Hashimoto, Y. \& Yabuuchi, E. (1989). Fluorometric deoxyribonucleic acid-deoxyribonucleic acid hybridization in microdilution wells as an alternative to membrane filter hybridization in which radioisotopes are used to determine genetic relatedness among bacterial strains. Int J Syst Bacteriol 39, 224-229.

Felsenstein, J. (1981). Evolutionary trees from DNA sequences: a maximum likelihood approach. J Mol Evol 17, 368-376.

Felsenstein, J. (1985). Confidence limits on phylogenies: an approach using the bootstrap. Evolution 39, 783-791.

Felsenstein, J. (1993). PHYLIP (phylogeny inference package), version 3.5c. Distributed by the author. Department of Genome Sciences, University of Washington, Seattle, USA.

Gregersen, T. (1978). Rapid method for distinction of Gram-negative from Gram-positive bacteria. Eur J Appl Microbiol Biotechnol 5, 123-127.

Groth, I., Schumann, P., Weiss, N., Martin, K. \& Rainey, F. A. (1996). Agrococcus jenensis gen. nov., sp. nov., a new genus of actinomycetes with diaminobutyric acid in the cell wall. Int J Syst Bacteriol 46, 234-239.

Hopwood, D. A., Bibb, M. J., Chater, K. F., Kieser, T., Bruton, C. J., Kieser, H. M., Lydiate, D. J., Smith, C. P. \& Ward, J. M. (1985). Preparation of chromosomal, plasmid and phage DNA. In Genetic Manipulation of Streptomyces. A Laboratory Manual, pp. 79-80. Norwich: John Innes Foundation.

Kimura, M. (1980). A simple method for estimating evolutionary rates of base substitutions through comparative studies of nucleotide sequences. J Mol Evol 16, 111-120.

Kluge, A. G. \& Farris, J. S. (1969). Quantitative phyletics and the evolution of anurans. Syst Zool 18, 1-32.

Komagata, K. \& Suzuki, K. (1987). Lipid and cell-wall analysis in bacterial systematics. Methods Microbiol 19, 161-207.

Kumar, S., Tamura, K. \& Nei, M. (2004). MEGA3: integrated software for molecular evolutionary genetics analysis and sequence alignment. Brief Bioinform 5, 150-163.

Lányí, B. (1987). Classical and rapid identification methods for medically important bacteria. Methods Microbiol 19, 1-67.

Mesbah, M., Premachandran, U. \& Whitman, W. B. (1989). Precise measurement of the $\mathrm{G}+\mathrm{C}$ content of deoxyribonucleic acid by high-performance liquid chromatography. Int J Syst Bacteriol 39, 159-167.

Minnikin, D. E., O’Donnell, A. G., Goodfellow, M., Alderson, G., Athalye, M., Schaal, A. \& Parlett, J. H. (1984). An integrated procedure for the extraction of bacterial isoprenoid quinones and polar lipids. J Microbiol Methods 2, 233-241.

Saitou, N. \& Nei, M. (1987). The neighbor-joining method: a new method for reconstructing phylogenetic trees. Mol Biol Evol 4, 406-425.

Sasser, M. (1990). Identification of bacteria by gas chromatography of cellular fatty acids. Newark, DE: MIDI Inc.

Shirling, E. B. \& Gottlieb, D. (1966). Methods for characterization of Streptomyces species. Int J Syst Bacteriol 16, 313-340.

Thompson, J. D., Gibson, T. J., Plewniak, F., Jeanmougin, F. \& Higgins, D. G. (1997). The CLUSTAL_X windows interface: flexible 
strategies for multiple sequence alignment aided by quality analysis tools. Nucleic Acids Res 25, 4876-4882.

Wayne, L. G., Brenner, D. J., Colwell, R. R., Grimont, P. A. D., Kandler, O., Krichevsky, M. I., Moore, L. H., Moore, W. E. C., Murray, R. G. E. \& other authors (1987). International Committee on Systematic Bacteriology. Report of the ad hoc committee on reconciliation of approaches to bacterial systematics. Int J Syst Bacteriol 37, 463-464.

Yoon, J.-H., Kang, S.-J., Kim, W. \& Oh, T.-K. (2007). Pigmentiphaga daeguensis sp. nov., isolated from wastewater of a dye works, and emended description of the genus Pigmentiphaga. Int J Syst Evol Microbiol 57, 1188-1191. 